\title{
A Search for Resistance in Lycopersicon spp. to Nacobbus aberrans
}

J. C. Veremis, Department of Nematology, University of California, Riverside 92521; G. B. Cap, Laboratorio de Nematologia, INTA Castelar, C. C. 25, (1712) Castelar, Buenos Aires, Argentina; and P. A. Roberts, Department of Nematology, University of California, Riverside 92521

\begin{abstract}
Veremis, J. C., Cap, G. B., and Roberts, P. A. 1997. A search for resistance in Lycopersicon spp. to Nacobbus aberrans. Plant Dis. 81:217-221.

Accessions of Lycopersicon cheesmanii, L. chmielewskii, L. esculentum var. cerasiforme, $L$. hirsutum, L. parviflorum, L. peruvianum, L. pennellii, L. pimpinellifolium, and three interspecific hybrids of $L$. peruvianum with $L$. esculentum, were screened for resistance to the false root-knot nematode (Nacobbus aberrans) in greenhouse tests. Variability in nematode reproduction levels was observed within L. chmielewskii accessions LA 2695 and LA 2663 in initial tests with $N$. aberrans from Argentina; however, interspecific hybrids of $L$. esculentum cv. UC$82 \times$ L. chmielewskii LA 2695, L. esculentum cv. UC- $82 \times$ L. chmielewskii LA 2663, and all the parent plants were susceptible in subsequent tests to the isolate of $N$. aberrans from Argentina and to an isolate from Mexico. The interspecific hybrids that possess the gene $M i$ and additional novel resistance to Meloidogyne spp. (root-knot nematodes) and all other exotic tomato accessions tested were susceptible to $N$. aberrans in our tests. Thus, we have been unable to identify or confirm resistance to two N. aberrans isolates in a range of Lycopersicon germ plasm accessions, including those that possess genes for resistance to root-knot nematodes.
\end{abstract}

Additional keywords: $M i$ gene, tomato

The false root-knot nematode, Nacobbus aberrans (Thorne) Thorne \& Allen, is an important pathogen of vegetable and field crops in the Americas. This nematode has been confused with widely diverse nematode taxa, and its occurrence has been underestimated because the saccate sedentary females and the symptomatic galls they induce can be mistaken easily for those associated with other saccate nematodes, particularly other gall-forming species such as Meloidogyne, from which Nacobbus derives its common name.

Luc's (13) revision of Nacobbus recognizes Sher's (22) synonyms within the genus. However, the validity of species, subspecies, and races is not fully resolved. Baldwin and Cap (1) emphasized that knowledge of Nacobbus diversity, biology, and control is limited by inadequate systematics. Studies with seven populations of $N$. aberrans from Argentina supported the existence of polymorphisms based on isozyme electrophoretic characters (6). Boluarte and Jatala (2) proposed an international race classification scheme with six plant species that differentiated seven physiological races and two variants of $N$. aberrans. Numerous races of $N$. aberrans

Corresponding author: P. A. Roberts

Telephone: (909) 787-4442

Fax: (909) 787-3719

E-mail: philip.roberts@ucr.edu

Accepted for publication 23 October 1996.

Publication no. D-1997-0106-06R

(C) 1997 The American Phytopathological Society have been observed in the highlands surrounding Lake Titicaca in southeastern Peru and northwestern Bolivia, and this region may be the center of origin of $N$. aberrans $(3,11) . N$. aberrans has a broad host range among crops and noncultivated plants representing at least 18 different botanical families $(3,10)$.

Galling on roots of tomato (Lycopersicon esculentum) cultivars that have the $M i$ gene, which confers resistance to Meloidogyne incognita, M. javanica, and $M$. arenaria, in soils infested with both $M$. incognita and $N$. aberrans is commonly observed. Sisler and Casaurang (23) found that all cultivated tomatoes tested were susceptible to $N$. aberrans, including cvs. Rossol and Planeuco (which carry Mi); however, they found resistance in some cultivars of pepper (Capsicum annuum). Resistant potato (Solanum tuberosum) germ plasm has also been found (8). Histopathological changes induced by $N$. aberrans in resistant potato roots involved a hypersensitive response of inhibition by the formation of necrotic cells surrounding the invading nematode (7). The feeding site induced by Nacobbus in a susceptible host is the formation of a spindle, heart, or irregularly shaped syncytium (3). Unlike either the giant cells induced by Meloidogyne spp. or the syncytia induced by Heterodera spp., wall ingrowths are absent in Nacobbus syncytia, thus more closely resembling the syncytia induced by Rotylenchulus.

The development of tomato cultivars resistant to $N$. aberrans would be an important contribution to tomato production, particularly for less developed countries (18). Resistance to Meloidogyne has been identified in the wild tomato Lycopersicon peruvianum and introgressed into tomato cultivars with considerable success (15). Novel heat-stable Meloidogyne resistance genes have been identified in L. peruvianum and transferred to hybrids with $L$. esculentum $(5,25)$. $M$. incognita and $M$. arenaria resistance in wild tomato has been characterized with differential interactions operating as a gene-for-gene system between specific $\mathrm{R}$ genes and nematode biotypes (25).

The objectives of this study were to test the novel heat-stable resistance to Meloidogyne spp. in L. peruvianum genotypes for resistance to $N$. aberrans and to search among other selected exotic Lycopersicon spp. germ plasm sources for resistance to two isolates of $N$. aberrans.

\section{MATERIALS AND METHODS}

Plant material. Seeds of exotic tomato accessions with an LA designation were obtained from the C. R. Rick Tomato Genetics Stock Center at the University of California, Davis; and those with a PI designation were from the Northeast Regional Plant Introduction Station at Geneva, New York. The exotic tomato seeds were pretreated as described by Rick and Borgnino (17) and germinated in vermiculite together with untreated seeds of $L$. esculentum cvs. Rutgers, Tropic, and UC82 used as susceptible controls and VFN-8 carrying the Meloidogyne resistance gene $M i$. Seedlings were grown in a greenhouse with $25^{\circ} \mathrm{C}$ air temperature and $45 \% \mathrm{RH}$, in the Nematode Isolation and Quarantine Facility (NIQF) at the University of California, Riverside. Clones were obtained agamically (cuttings from young stems three nodes in length) from the following genotypes: Lycopersicon chmielewskii LA 2695, LA 2663, and their interspecific hybrids with $L$. esculentum; L. esculentum cv. UC-82 $\times$ L. peruvianum PI 2704352R2; L. esculentum line ms-31 $\times$ L. peruvianum PI 126443-1MH (4); and PI 126443-1MH $\times$ EPP-1 (24). Stem segments were dusted with rooting powder containing $2 \mathrm{~g}$ of 1-naphthaleneacetamide, $1 \mathrm{~g}$ of indole-3-butyric acid, and $4.40 \mathrm{~g}$ of thiram per liter. The dusted cuttings were planted in vermiculite and maintained in a mist chamber for at least 1 week, when cuttings started to produce new roots.

Hybrids of $L$. esculentum and $L$. chmielewskii LA 2695 and LA 2663. 
Pollen from clones of the two parents $L$. chmielewskii LA 2695 and LA 2663 was collected and stored as described by McGuire (14). One day before anthesis (when the petals changed from green-yellow to light yellow), flowers of $L$. esculentum UC-82 were emasculated and handchmielewskii LA 2695 or LA 2663. Pollinated ovaries were enclosed with paper bags or capsules to avoid cross-pollination.

Nematode cultures. The $N$. aberrans isolates were from infested tomato fields in Gorina, Buenos Aires, Argentina, and in Chapingo, Mexico. The isolates were reared in an isolation room at $25^{\circ} \mathrm{C}$ and $45 \% \mathrm{RH}$ on tomato cvs. Rutgers or Tropic, grown in 4-liter disposable pots filled with steam-sterilized loamy sand $(78 \%$ sand, $22 \%$ silt) and fertilized with Osmocote. After 60 to 70 days, soil and roots in the pots were allowed to dry for 1 week, placed in plastic bags, and transferred to a refrigerator at $4{ }^{\circ} \mathrm{C}$ for another week before use as an inoculum source. The drying and chilling treatment proved to be effective in breaking the dormancy of the fourth-stage juveniles (J4), and possibly also the dormancy of the eggs.

Screening of tomato genotypes. Screening was carried out in the NIQF under state and federal regulations. Onemonth-old tomato seedlings and rooted cuttings were transferred to $600 \mathrm{~cm}^{3}$ disposable pots filled with steam-sterilized loamy sand soil infested with $N$. aberrans. This isolate was reared in the same soil on tomato for at least six generations, and the final number of combined $\mathrm{J} 3, \mathrm{~J} 4$, and pollinated with pollen from clones of $L$.

young vermiform females was approximately $150 / 100 \mathrm{~cm}^{3}$ of soil. Numerous viable eggs were also present in the soil used for the screening. Two weeks after the plants were transferred to infested soil, $5 \mathrm{~g}$ of chopped infected tomato roots mixed with infested soil of the same $N$. aberrans isolate was added to each pot. Seventy-five days after transfer to infested soil, the root systems were washed free of soil under tap water, damp-dried with paper towels, and weighed. Roots were immersed overnight in 75 ppm erioglaucine (Aldrich, St. Louis, MO) stain solution to highlight egg masses for counting (16). Eggs were extracted from roots macerated in $1 \% \mathrm{NaOCl}$ solution in a commercial blender and rinsed through a series of sieves with openings of 850,106 , and $38 \mu \mathrm{m}$. The egg suspension was adjusted to a known volume, and the number of eggs was counted under a dissecting microscope (9). The number of eggs per gram of root was calculated by dividing the total number of eggs per root system by the total fresh root weight. Index of resistance (IR) was calculated by using the number of eggs per gram of root of the entry as a percentage of the number on the susceptible tomato cv. Rutgers. Galling index values per root system were as follows: $1=$ trace infections with few small galls, $2=$ less than $25 \%$ of roots galled, $3=$ 25 to $50 \%$ of roots galled, $4=51$ to $75 \%$ of roots galled, and $5=$ more than $75 \%$ of roots galled (12). Plants were considered resistant when the galling index was less than 2. Means of eggs per gram of root and galling index for each tomato line were subjected to ANOVA with the Super

Table 1. Reproduction (eggs per g of root) of and root galling by an isolate of Nacobbus aberrans from Argentina on Lycopersicon spp. genotypes in a greenhouse experiment

\begin{tabular}{|c|c|c|c|c|c|c|c|}
\hline \multirow{2}{*}{$\begin{array}{l}\text { Tomato } \\
\text { genotypes }\end{array}$} & \multirow[b]{2}{*}{$\mathbf{n}$} & \multirow{2}{*}{$\begin{array}{c}\text { Fresh root } \\
\text { wt. (g) }\end{array}$} & \multicolumn{2}{|c|}{ Eggs per g of root } & \multirow{2}{*}{$\begin{array}{l}\text { Galls per } \\
\text { root syst. }\end{array}$} & \multicolumn{2}{|c|}{ IR $^{\mathrm{x}}$ value } \\
\hline & & & Mean & Range & & $<10 \%$ & $>10 \%$ \\
\hline LA 2695 & 14 & 18 & $1,409 \mathrm{~g}^{\mathrm{y}}$ & $290-3,601$ & 16 & 5 & 9 \\
\hline LA 153 & 10 & 42 & $1,411 \mathrm{~g}$ & $248-4,993$ & 65 & 4 & 6 \\
\hline LA 2663 & 11 & 35 & $1,497 \mathrm{fg}$ & $105-3,358$ & 43 & 4 & 7 \\
\hline LA 1973 & 4 & 28 & $1,633 \mathrm{fg}$ & $738-3,558$ & 56 & 2 & 2 \\
\hline LA 1322 & 3 & 20 & $2,263 \mathrm{e}-\mathrm{g}$ & $1,774-3,056$ & 41 & & 3 \\
\hline LA 2260 & 7 & 58 & $3,064 \mathrm{e}-\mathrm{g}$ & $1,517-4,649$ & 90 & & 7 \\
\hline LA 1044 & 2 & 42 & $3,174 \mathrm{e}-\mathrm{g}$ & $2,594-3,755$ & 75 & & 2 \\
\hline PI 270435 & 3 & 16 & $3,392 \mathrm{~d}-\mathrm{g}$ & $1,333-4,533$ & $>100$ & & 3 \\
\hline PI 129152 & 9 & 40 & $3,716 \mathrm{~d}-\mathrm{g}$ & $1,558-10,850$ & $>100$ & & 9 \\
\hline LA 716 & 9 & 14 & $4,327 \mathrm{~d}-\mathrm{g}$ & $833-8,338$ & 72 & & 9 \\
\hline LA 1942 & 6 & 14 & $4,373 \mathrm{c}-\mathrm{g}$ & $638-14,761$ & 37 & 2 & 4 \\
\hline LA 317 & 6 & 24 & $4,880 \mathrm{c}-\mathrm{g}$ & $271-8,233$ & 54 & 1 & 5 \\
\hline VFN & 17 & 41 & $5,773 b-f$ & $1,769-12,160$ & $>100$ & & 17 \\
\hline PI 126443 & 10 & 27 & $6,232 \mathrm{~b}-\mathrm{e}$ & $3,243-12,125$ & $>100$ & & 10 \\
\hline PI 126440 & 11 & 35 & $6,276 \mathrm{~b}-\mathrm{e}$ & $2,533-13,678$ & $>100$ & & 11 \\
\hline PI 128657 & 10 & 30 & 7,434 b-d & $4,000-12,861$ & $>100$ & & 10 \\
\hline PI 128656 & 12 & 24 & $8,110 b c$ & $2,760-11,726$ & $>100$ & & 12 \\
\hline Rutgers & 19 & 44 & $8,407 \mathrm{bc}$ & $5,240-11,430$ & $>100$ & & 19 \\
\hline $\mathrm{F}_{1} \mathrm{G}^{\mathrm{z}}$ & 4 & 18 & $8,944 \mathrm{~b}$ & $7,500-11,167$ & $>100$ & & 4 \\
\hline $\mathrm{F}_{1} \mathrm{P}^{\mathrm{z}}$ & 4 & 20 & $9,017 \mathrm{~b}$ & $8,444-9,900$ & $>100$ & & 4 \\
\hline LA 426 & 2 & 23 & $13,149 \mathrm{ab}$ & $5,611-20,687$ & $>100$ & & 2 \\
\hline
\end{tabular}

${ }^{\mathrm{x}}$ Index of resistance, number of eggs per $\mathrm{g}$ of root as a percentage of the numbers on the susceptible tomato cv. Rutgers.

y Values followed by the same letter are not significantly different $(P \leq 0.05)$ according to Duncan's new multiple range test.

${ }^{\mathrm{z}} \mathrm{F}_{1} \mathrm{G}$ and $\mathrm{F}_{1} \mathrm{P}$, interspecific hybrids between L. esculentum cv. UC82 $\times$ L. peruvianum $\mathrm{PI} 270435$ and L. esculentum line ms-31 $\times$ L. peruvianum var. glandulosum PI 126443 , respectively.
ANOVA program (Abacus Concepts Inc., Berkeley, CA), which accounted for variable numbers of replicate plants per test line.

\section{RESULTS}

Reaction of Lycopersicon genotypes to N. aberrans from Argentina. Lycopersicon cheesmanii LA 426 supported the most nematode reproduction, with a mean of 13,149 eggs per $g$ of root, higher than the majority of the other treatments (Table 1). Reproduction levels on $L$. esculentum cvs. Rutgers and VFN-8, L. peruvianum PI 128656 and PI 128657, L. peruvianum var. glandulosum PI 126440 and PI 126443 , and their interspecific hybrids did not differ from LA 426, indicating a susceptible reaction in each case, with 5,773 to 9,017 eggs per $g$ of root and a high galling response (>100 galls per root system). A second group of plant genotypes was intermediate in reaction and did not differ in numbers of eggs per $\mathrm{g}$ of root from $L$. esculentum cv. VFN-8. This group included L. parviflorum LA 1322, L. esculentum var. cerasiforme LA 2260, L. cheesmanii LA 1044 and LA 317, L. pennellii LA 716 and LA 1942, and L. peruvianum PI 270435 and PI 129152.

Four accessions-L. chmielewskii LA 2695 and LA 2663, L. peruvianum LA 153, and $L$. peruvianum var. glandulosum LA 1973 - supported significantly less reproduction than did the susceptible tomato control cvs. VFN-8 and Rutgers. The wide range of scores within an accession indicated segregation for resistance. The average numbers of galls per root system in $L$. chmielewskii LA 2695 and LA 2663 (16 and 43 , respectively) were less than half the number observed in the susceptible control, and the average gall numbers for L. peruvianum LA 153 and L. peruvianum var. glandulosum LA 1973 (65 and 56, respectively) were also lower than numbers

Table 2. Reproduction (eggs per g of root) of an isolate of Nacobbus aberrans from Mexico on Lycopersicon esculentum UC82 $\times L$. chmielewskii hybrid lines and their $L$. chmielewskii parental accessions in a greenhouse experiment

\begin{tabular}{lc}
\hline Tomato genotype & Eggs per g of root \\
\hline L. esculentum & \\
Tropic & $774 \mathrm{a}^{\mathrm{y}}$ \\
VFN-8 & $902 \mathrm{a}$ \\
Hybrid lines & \\
UC82 $\times$ LA 2663 & $4,640 \mathrm{~b}$ \\
UC82 $\times$ LA 2695 & $6,905 \mathrm{c}$ \\
L. chmielewskii & \\
LAz 2663 & $1,638 \mathrm{a}$ \\
LA 2695 & $3,611 \mathrm{~b}$
\end{tabular}

y Values followed by the same letter are not significantly different $(P \leq 0.05)$ according to Duncan's new multiple range test. Values are means of five replicate root systems.

${ }^{\mathrm{z}}$ Local accessions, maintained in the $\mathrm{C}$. $\mathrm{M}$. Rick Tomato Genetics Stock Center, University of California, Davis. 
in the susceptible controls. Also, all the genotypes with egg numbers greater than VFN-8 had heavy galling responses.

In L. chmielewskii LA 2695 and LA 2663, L. peruvianum LA 153 , and L. peruvianum var. glandulosum LA 1973, more than $50 \%$ of the total plants for each entry had individual IR values below $10 \%$ (Table 1). Two accessions, L. pennellii LA 1942 and L. cheesmanii LA 317, which supported intermediate numbers of eggs on roots and low numbers of root galls, had two of four and one of five plants, respectively, that had IR values less than 10, suggesting that these accessions may be segregating for resistance to $N$. aberrans. The average root weight was variable among treatments, and there may be a carrying-capacity effect in that fewer infection sites were available to the nematode on plants with small root mass. For example, the average root weight for the most susceptible entry, $L$. cheesmanii LA 426, was $23 \mathrm{~g}$, whereas the average root weights of the putative resistant $L$. chmielewskii LA 2695 and $L$. peruvianum LA 153 were 18 and 42, respectively. The morphology and health of the roots in the wild tomato accessions varied within the accessions.

Reactions of $L$. chmielewskii hybrids to $N$. aberrans from Mexico. The $L$. esculentum $\times$ L. chmielewskii crosses produced variable numbers of viable $F_{1}$ seeds. Most of the mature $F_{1}$ seeds germinated, and seedlings grew vigorously. Their morphological characters of leaf shape, sepals, hirsuteness, indeterminate growth habit, fruit color, and length of style exerted from the anther cone were intermediate between the L. esculentum and L. chmielewskii parents in both crosses (data not shown). The number of eggs per $g$ of root produced on the susceptibles Tropic and VFN-8 was high in each case and confirmed that a successful uniform inoculum was achieved (Table 2). The hybrid UC-82 $\times L$. chmielewskii LA 2695 supported significantly higher reproduction than did the other genotypes. The numbers of eggs per $\mathrm{g}$ of root produced on L. chmielewskii LA 2663 and LA 2695 were higher than on the susceptible cultivars, and their hybrids supported even higher egg production $(P \leq$ $0.05)$. Without exception among replicates within the treatments, all plants had high numbers of galls per root system (data not shown). The average root weight was variable among treatments, and this may have affected the egg production level to some extent. For example, the average root weight for the most susceptible entry, UC82 $\times$ L. chmielewskii LA 2695, was 2.7 $\mathrm{g}$, and for Tropic it was $12.6 \mathrm{~g}$.

Rescreening of Lycopersicon clones to $N$. aberrans from Argentina. Clones of plants from several accessions that were putatively resistant to the $N$. aberrans isolate from Argentina were re-screened with the same isolate (Table 3). Although significant differences $(P \leq 0.05)$ were observed in mean numbers of eggs per $g$ of root produced on the clones, they all gave a susceptible reaction (IR values 43 to 139 ). In addition, all the genotypes had heavy galling responses, with numbers above 100 in each case.

Reactions of Lycopersicon spp. to $N$. aberrans from Argentina. Additional accessions of several Lycopersicon spp. tested with the $N$. aberrans isolate from Argentina all had high mean galling indices, ranging from 3.5 to 5.0 , similar to those of $L$. esculentum cvs. Tropic and VFN-8 (Table 4). The interspecific bridge hybrid $L$. peruvianum var. glandulosum PI 126443-1MH $\times$ EPP-1 had an average galling index of 4.4. These reactions indicated high susceptibility in each case.

\section{DISCUSSION}

Within some accessions in the original screening, striking variability occurred in which more than $50 \%$ of the individuals supported very low $N$. aberrans reproduction, suggesting segregation for resistance. However, retesting of the more promising

Table 3. Reproduction of an isolate of Nacobbus aberrans from Argentina on putative resistant $L y$ copersicon spp. genotypes in a greenhouse experiment

\begin{tabular}{|c|c|c|c|c|c|}
\hline \multirow[b]{2}{*}{ Tomato genotype } & \multirow[b]{2}{*}{$\mathbf{n}$} & \multirow{2}{*}{$\begin{array}{c}\text { Root fresh } \\
\text { wt. (g) }\end{array}$} & \multicolumn{2}{|c|}{ Eggs per $g$ of root } & \multirow[b]{2}{*}{ IR $^{\mathrm{x}}$ value $(\%$} \\
\hline & & & Mean & Range & \\
\hline \multicolumn{6}{|l|}{ L. esculentum } \\
\hline Rutgers & 5 & 98 & $17,147 \mathrm{~b}^{\mathrm{y}}$ & $13,732-22,951$ & 100 \\
\hline VFN & 5 & 100 & $13,858 \mathrm{~b}$ & $11,716-19,353$ & 80 \\
\hline \multicolumn{6}{|l|}{ L. chmielewskii } \\
\hline $\mathrm{LA}^{\mathrm{z}} 2663$ & 5 & 21 & $15,104 \mathrm{~b}$ & $7,366-19,583$ & 88 \\
\hline LA 2695 & 5 & 23 & $8,926 \mathrm{c}$ & $6,852-13,095$ & 52 \\
\hline \multicolumn{6}{|l|}{ L. peruvianum } \\
\hline LA 153 & 5 & 111 & $7,410 \mathrm{c}$ & $6,049-8,670$ & 43 \\
\hline LA 1973 & 2 & 27 & $23,833 \mathrm{a}$ & $21,434-26,232$ & 139 \\
\hline \multicolumn{6}{|l|}{ L. pennellii } \\
\hline LA 1942 & 5 & 8 & $8,796 \mathrm{c}$ & $2,592-15,000$ & 52 \\
\hline
\end{tabular}

${ }^{\mathrm{x}}$ Index of resistance, number of eggs per $\mathrm{g}$ of root as a percentage of the number on the susceptible tomato cv. Rutgers.

y Values followed by the same letter are not significantly different $(P \leq 0.05)$ according to Duncan's new multiple range test.

${ }^{\mathrm{z}}$ Local accessions, maintained in the C. M. Rick Tomato Genetics Stock Center at the University of California, Davis. individual clones from these accessions indicated that they were susceptible escapes from nonuniform soil inoculum in the first experiment. Although uniform soil infection level is difficult to achieve or confirm, increasing the level of inoculum reduced the chance of escapes as demonstrated in our later tests. Resistant entries such as resistant bean, pepper, or potato cultivars also can be planted for helpful comparative purposes.

Table 4. Galling caused by an Argentina isolate of Nacobbus aberrans on Lycopersicon spp. accessions in a greenhouse experiment

\begin{tabular}{lcl}
\hline Tomato genotype & $\mathbf{n}$ & Galling index \\
\hline L. esculentum & & \\
Tropic & 5 & $5.0 \mathrm{e}$ \\
VFN-8 & 5 & $5.0 \mathrm{e}$ \\
Hybrid & & \\
PI 126443-1MH $\times$ & 5 & $4.4 \mathrm{~cd}$ \\
EPP-1 & & \\
L. peruvianum & & \\
PI 126448 & 5 & $5.0 \mathrm{e}$ \\
PI 126926 & 3 & $5.0 \mathrm{e}$ \\
PI 128646 & 7 & $5.0 \mathrm{e}$ \\
PI 129152 & 11 & $5.0 \mathrm{e}$ \\
PI 247087 & 6 & $4.5 \mathrm{c}-\mathrm{e}$ \\
PI 251305 & 6 & $4.5 \mathrm{c}-\mathrm{e}$ \\
PI 251307 & 3 & $4.0 \mathrm{bc}$ \\
LA 111 & 6 & $4.5 \mathrm{c}-\mathrm{e}$ \\
LA 464 & 4 & $5.0 \mathrm{e}$ \\
LA 1708 & 9 & $4.6 \mathrm{c}-\mathrm{e}$ \\
LA 2770 & 3 & $4.0 \mathrm{bc}$ \\
LA 2774 & 4 & $5.0 \mathrm{e}$ \\
L. chmielewskii & & \\
LA 2663 & 6 & $4.6 \mathrm{c}-\mathrm{e}$ \\
LA 2695 & 6 & $4.2 \mathrm{c}$ \\
LA 1028 & 4 & $3.5 \mathrm{ab}$ \\
LA 1317 & 3 & $4.0 \mathrm{bc}$ \\
LA 1325 & 4 & $4.5 \mathrm{c}-\mathrm{e}$ \\
L. pimpinellifolium & & \\
PI 143524 & 4 & $4.0 \mathrm{bc}$ \\
PI 126436 & 3 & $5.0 \mathrm{e}$ \\
PI 126932 & 3 & $5.0 \mathrm{e}$ \\
PI 126937 & 3 & $5.0 \mathrm{e}$ \\
PI 230327 & 3 & $5.0 \mathrm{e}$ \\
PI 251320 & 3 & $4.0 \mathrm{bc}$ \\
PI 375937 & 3 & $5.0 \mathrm{e}$ \\
PI 379058 & 6 & $5.0 \mathrm{e}$ \\
PI 390691 & 3 & $5.0 \mathrm{e}$ \\
LA 1269 & 6 & $5.0 \mathrm{e}$ \\
LA 1280 & 4 & $4.5 \mathrm{c}-\mathrm{e}$ \\
L. hirsutum & & \\
PI 127826 & 5 & $4.8 \mathrm{c}-\mathrm{e}$ \\
PI 134418 & 3 & $5.0 \mathrm{e}$ \\
PI 390514 & 6 & $4.8 \mathrm{c}-\mathrm{e}$ \\
PI 415127 & 3 & $5.0 \mathrm{e}$ \\
LA 407 & 3 & $5.0 \mathrm{e}$ \\
LA 2090 & 4 & $4.5 \mathrm{c}-\mathrm{e}$ \\
\hline G $117 n g$ \\
\hline
\end{tabular}

${ }^{\mathrm{w}}$ Galling indices were calculated as follows: 1 $=$ trace infections with few small galls, $2=$ less than $25 \%$ roots galled, $3=25$ to $50 \%$ roots galled, $4=51$ to $75 \%$ roots galled, and 5 $=$ more than $75 \%$ roots galled. Values followed by the same letter are not significantly different $(P \leq 0.05)$ according to LSD test.

x Interspecific hybrid of $L$. peruvianum var. glandulosum PI 126443-1MH $\times$ EPP-1.

y Plant introductions, maintained in the Northeast Regional Plant Introduction Station at Geneva, New York.

${ }^{\mathrm{z}}$ Local accessions, maintained in the $\mathrm{C} . \mathrm{M}$. Rick Tomato Genetics Stock Center at the University of California, Davis. 
The dormancy mechanism of Nacobbus spp. is not clearly understood, but some authors suggest that $N$. aberrans requires drought conditions to break dormancy of J4 (10). In our study, chilling combined with drought was observed to increase the infectivity of the nematode inoculum. When eggs or $\mathbf{J} 2$ were extracted from tomato roots and used directly for inoculum, little or no infection occurred.

The positive association between the amount of root galling and the amount of egg production by $N$. aberrans on susceptible roots was similar to evaluations for Meloidogyne spp. reproduction and root galling. Occasionally, we observed low galling and high egg production, but never vice versa. A comparison of the egg production and galling evaluation results suggests that galling index can be used for $N$. aberrans; a good correlation exists between the amount of galling and the ability to support egg production of $N$. aberrans, as has been used in screening for resistance to Meloidogyne spp. The root gall index should indicate the reproductive capability of $N$. aberrans in tomato and allow detection of resistance less laboriously in large screenings than would determination of egg production. Each replicate entry can be genetically different from others of the same line for many traits, including host suitability. Some accessions had low galling indices, which raised questions about whether the nature of variability was genetic in these accessions, even though they supported high levels of nematode reproduction. We have observed similar relationships within Lycopersicon genotypes evaluated for Meloidogyne resistance. The low numbers of galls compared with the susceptible controls in these accessions may be an important characteristic for conferring field tolerance; however, no meaningful index of tolerance is possible on the wild tomato plants because of the difficulty of determining the relative growth or yield of a wild accession compared with commercial tomato cultivars.

L. esculentum cv. VFN-8, bearing the Meloidogyne resistance gene $\mathrm{Mi}$, was fully susceptible to $N$. aberrans, confirming the observations by Sisler and Casaurang (23) with cultivars bearing $M i$. Susceptibility to $N$. aberrans was observed also for the $L$. peruvianum accessions that carry novel resistance genes to $M$. incognita. The interspecific embryo rescue and bridge line hybrids carrying novel Meloidogyne resistance genes $(5,25)$ were also highly susceptible to these two isolates of $N$. aberrans. Therefore, we can conclude that the known Meloidogyne resistance genes do not confer resistance to $N$. aberrans. It would be interesting to know whether other isolates of $N$. aberrans behave similarly to the two tested isolates for reaction to the novel Meloidogyne resistance. Evidently, host-parasite specific recognition mechanisms for $N$. aberrans are not the same as for Meloidogyne. This result is not unexpected considering that clear differences in compatibility-incompatibility relationships for Meloidogyne resistance genes occur within and between Meloidogyne species $(19,21,25)$. Nacobbus and Meloidogyne spp. belong to different families and elicit a different susceptible response in the same host; therefore, it is not surprising that they have different recognition mechanisms through parallel evolution to induce a galling response in the host. However, conserved genetic control in the plant and the nematode and common stabilizing natural selection mechanisms should be operating to allow for morphological similarity to be derived from the co-evolution.

These results suggest that the tested entries of L. chmielewskii, L. peruvianum, $L$. peruvianum var. glandulosum, $L$. hirsutum, and $L$. pimpinellifolium do not constitute promising sources of resistance to the isolates of $N$. aberrans from Argentina and Mexico. However, additional screening in Lycopersicon for resistance to $N$. aberrans should be made, because the entries for each accession tested here are limited compared with the large germ plasm resource of wild relatives of tomato. Roberts and Stone (20) proposed that the primary condition in Solanum spp. was susceptibility to cyst nematodes (Globodera spp.) and that resistance was developed as a consequence of nematode attack. Thus, in nematode centers of origin, a mixture of susceptible and resistant host genotypes is present (20). The susceptible L. chmielewskii accessions LA 2695 and LA 2663 were collected in Cuzco, relatively close to Lake Titicaca (southeast Peru and northwest Bolivia), a region that is proposed to be the center of origin of $N$. aberrans (11). From an evolutionary standpoint, it would be interesting to find low parasitism rates of different $N$. aberrans isolates from that area on Lycopersicon accessions collected around Lake Titicaca. An exhaustive screening of wild Lycopersicon species indigenous to the Lake Titicaca area would be important for identification of potential sources of $N$. aberrans resistance if they have been selected and are not extinct. The L. chmielewskii LA 2695 and LA 2663 accessions are also susceptible to all Meloidogyne isolates tested in our laboratory (unpublished data). The screening of this material and of other Solanaceae with several populations of $N$. aberrans will be valuable in clarifying the relationships among sedentary endoparasitic nematodes and their hosts. Resistance to $N$. aberrans has been found in two other genera of the Solanaceae, Solanum and Capsicum $(3,11,23)$, and Lycopersicon-Solanum intergeneric hybrids hold potential to improve resistance to nematodes as well as other desirable characters not present in $L$. esculentum.

\section{LITERATURE CITED}

1. Baldwin, J. G., and Cap, G. B. 1990. Systematics of Nacobbus, the false root-knot nematode. Pages 101-112 in: Nematology: From molecule to ecosystem. F. J. Gommers and P. W. T. Maas, eds. Proc. Int. Nematology Congr., 2nd. The Netherlands.

2. Boluarte, T., and Jatala, P. 1992. Development of an international race classification scheme for determination of physiological races of Nacobbus aberrans. Nematropica 22:119.

3. Canto, M. 1990. Life cycle and pathogenicity of Nacobbus aberrans (Thorne, 1935) Thorne and Allen, 1944. Pages 113-127 in: Nematology: From molecule to ecosystem. F. J. Gommers and P. W. T. Maas, eds. Proc. Int. Nematology Congr., 2nd. The Netherlands.

4. Cap, G. B. 1991. Inheritance and phenotypic expression of heat stable resistance to Meloidogyne spp. in Lycopersicon peruvianum and its transfer to edible tomato. Ph.D. thesis. University of California, Riverside.

5. Cap, G. B., Roberts, P. A., Thomason, I. J., and Murashige, T. 1991. Embryo culture of Lycopersicon esculentum $\times$ L. peruvianum hybrid genotypes possessing heat-stable resistance to Meloidogyne incognita. J. Am. Soc. Hortic. Sci. 116:1082-1088.

6. Doucet, E. M., and Gardenal, C. N. 1992. The genus Nacobbus in Argentina. 4. Preliminary comparison of populations of $N$. aberrans (Thorne, 1935) Thorne \& Allen, 1944 by means of isoenzyme phenotypes. Nematropica 22:243-246.

7. Finetti Sialer, M. 1990. Histological changes induced by Nacobbus aberrans in resistant and susceptible potato roots. Revue Nematol. 13:155-160.

8. Franco, J., Montecinos, R., and Ontuno, N. 1992. Resistance to Nacobbus aberrans in cultivated potatoes. Nematropica 38:412.

9. Hussey, R. S., and Barker, K. R. 1973. A comparison of methods of collecting inocula of Meloidogyne spp., including a new technique. Plant Dis. Rep. 57:1025-1028.

10. Inserra, R. N., Griffin, G. D., and Anderson, J. L. 1985. The false root-knot nematode $\mathrm{Na}$ cobbus aberrans. Utah Agric. Exp. Stn. Res. Bull. 510.

11. Jatala, P. 1985. El nematodo falso nodulador de la raíz. Pages 47-55 in: Fitonematologia Avanzada I, Montecillos, Mexico. N. M. Mendoza and I. J. Thomason, eds

12. Kinloch, R. A. 1990. Screening for resistance to root-knot nematodes. Pages 16-23 in Methods for Evaluating Plant Species for Resistance to Plant-Parasitic Nematodes. J. L. Starr, ed. Society of Nematologists, Hyattsville, Maryland.

13. Luc, M. 1987. A reappraisal of Tylenchina (Nemata). 7. The family Pratylenchidae Thorne, 1949. Revue Nematol. 10:203-218.

14. McGuire, D. C. 1952. Storage of tomato pollen. Proc. Am. Soc. Hortic. Sci. 60:419424.

15. Medina Filho, H. P., and Tanksley, S. D. 1983. Breeding for nematode resistance. Vol. 1 Pages 904-923 in: Handbook of Plant Cell Culture. D. A. Evans, W. R. Sharp, P. V. Ammirato, and Y. Yamada, eds. Macmillan Publishing Company, London.

16. Omwega, C. O., Thomason, I. J., and Roberts, P. A. 1988. A nondestructive technique for screening bean germ plasm for resistance to Meloidogyne incognita. Plant Dis. 72:970-972.

17. Rick, C. M., and Borgnino, F. H. 1989. A method for improving seed germination of Solanaceous species. Department of Vegetable Crops, University of California, Davis.

18. Roberts, P. A. 1992. Current status of the availability, development and use of host plant resistance to nematodes. J. Nematol. 24:213-227. 
19. Roberts, P. A., Dalmasso, A., Cap, G. B., and Castagnone-Sereno, P. 1990. Resistance in Lycopersicon peruvianum to isolates of $\mathrm{Mi}$ gene-compatible Meloidogyne populations. J. Nematol. 22:585-589.

20. Roberts, P. A., and Stone, A. R. 1981. Host ranges of Globodera species within Solanum subgenus Leptostemonum. Nematologica 27:172-189.

21. Roberts, P. A., and Thomason, I. J. 1986. Variability in reproduction of isolates of
Meloidogyne incognita and $M$. javanica on resistant tomato genotypes. Plant Dis. 70:547551.

22. Sher, S. A. 1970. Revision of the genus $\mathrm{Na}$ cobbus Thorne and Allen, 1944 (Nematoda: Tylenchoidea). J. Nematol. 2:228-235.

23. Sisler de, G. M., and Pelicano de Casaurang, A. 1983. Reacción de cultivares de tomate y pimiento a Nacobbus aberrans (Nematoda, Nacobbidae). Revista de la Facultad de Agronomia, Buenos Aires, Argentina. Vol.
4:79-82.

24. Veremis, J. C. 1995. Genetic characterization of novel resistance to root-knot nematodes (Meloidogyne spp.) in wild tomato (Lycopersicon peruvianum). Ph.D. thesis. University of California, Riverside.

25. Veremis, J. C., and Roberts, P. A. 1996. Differentiation of Meloidogyne incognita and $M$. arenaria novel resistance phenotypes in $L y$ copersicon peruvianum and derived bridge lines. Theor. Appl. Genet. 93:960-967. 